\title{
MAJESTY
}

MASPUL JOURNAL OF ENGLISH STUDIES

| ISSN 2567-0157)(Online) |

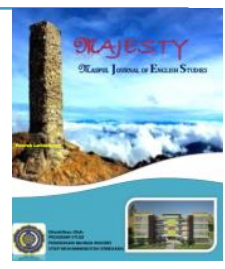

\section{Retailing in Electronic Commerce: Travel and Tourism Services Online}

\section{Mustakim Mustakim}

Department of English Education STKIP Muhammadiyah Enrekang, Indonesia

\section{ARTICLE INFO \\ Article History: \\ Received 20 November 2018 \\ Accepted 7 January 2019}

\section{Keywords:}

Retailing

Electronic

Commerce

Travel and Tourism

\begin{abstract}
In recent years, the emergence of new tourism services and products, coupled with a rapid increase in tourism demand, have driven the wide-scale adoption of ITs in general, and in particular, the Internet as an electronic intermediary. In other words, the Internet serves as a new communication and distribution channel for e-travelers and suppliers of travel services and products. This new channel also enables tourism businesses to improve their competitiveness and performance. The aim of this paper is to highlight how retailing in e-commerce (travel tourism service online) according to the experts is, special services, such as wireless services, direct marketing, alliances and consortia, benefits and limitation of travel online service, the impact of EC on the travel industry, corporate travel and intelligent agents in travel services.
\end{abstract}

\section{INTRODUCTION}

A retailer is a sales intermediary, a seller that operates between manufactures and customers. Even though many manufactures sell directly to consumers, they supplement their sales through wholesalers and retailers (a multichannel approach). In the physical world, retailing is done in stores (factory outlets) that customers must visit in order to make a purchase. Companies that produce a large number of products, such as Procter \& Gamble, must use retailers for efficient distribution. However, even if you sell only a relatively few products (e.g., Kodak), you

@Majesty Journal 2019

$\triangle$ Corresponding author: Address : STKIP Muhammadiyah Enrekang Email : kimchangi00@gmail.com
Published by STKIP Muhammadiyah Enrekang ISSN 2567-0157 (Online) 
still may need retailers in order to reach a large number customers. Catalog sales offer companies and customers a respite from the restraints of space and time: Catalog free a retailer from the need for a physical store from which to distribute products, and customers can browse catalogs on their own time. With the ubiquity of the Internet, the next logical step was for retailing to move online. Online retail sales are called electronic retailing, or e-tailing, and those who conduct retail business online are called e-tailers. E-tailing also can be conducted through auctions. E-tailing makes it easier for manufacturer to sell directly to the customer, cutting out the intermediary [1].

\section{RETAILING AND ELECTRONIC COMMERCE-THE THEORITICAL FRAMEWORK}

Investopedia explains electronic retailing requires businesses to tailor traditional business models to the rapidly changing face of the Internet and its users. E-tailers are not restricted solely to the Internet, and some brick-and-mortar businesses also operate websites to reach consumers. Online retailing is normally referred to as e-tailing [2].

According to the editor-in-chief of International Journal of Electronic Commerce, Vladimir Zwass, 'Electronic commerce is sharing business information, maintaining business relationships and conducting business transactions by means of telecommunications networks'[3]. He maintains that in its purest form, electronic commerce has existed for over 40 years, originating from the electronic transmission of messages during the Berlin airlift in 1948[4]. From this, electronic data interchange (EDI) was the next stage of ecommerce development. In the 1960s a cooperative effort between industry groups produced a first attempt at common electronic data formats. The formats, however, were only for purchasing, transportation and finance data, and were used primarily for intra-industry transactions. It was not until the late 1970s that work began for national Electronic Data Interchange (EDI) standards, which developed well into the early 1990s.

Some of the definitions of e-commerce often heard and found in publications and the media are:

Electronic Commerce (EC) is where business transactions take place via telecommunications networks, especially the Internet[5]. Electronic commerce describes the buying and selling of products, services, and information via computer networks including the Internet[6]. Electronic commerce is about doing business electronically[7]. Ecommerce, ecommerce, or electronic commerce is defined as the conduct of a financial transaction by electronic means[8].

\section{Travel and Tourism Services Online}

The internet is an ideal place to plan, explore, and arrange almost trip. Convenience and potential savings are available through special sales and elimination of travel agents by buying directly from service providers.

Some major travel-related Web sites are expedia.com, orbitz.com, travelocity.com, asiatravel.com, hotwire.com, 
travelweb.com, eurovacations.com, and princeline.com. Online travel services also are provided by all major airlines, vacation services, large conventional travel agencies, trains (e.g., Amtrak.com), car rental agencies, hotels, commercial portals, and tour companies. Publishers of travel guides such as Fodors and Lonely Planet provide considerable amounts of travel-related information on their Web sites (fodors.com and lonelyplanet.com), as well as selling travel service there. Online ticket consolidator ebookers.com and travel information broker TIScover.com are linking up to create a comprehensive Web-travel resource.

The revenue models of online travel services include direct revenues (commissions), revenue from advertising, consultancy fees, subscription or membership fees, revenue-sharing fees, and more. Other important considerations for the growth of online travel services are the value propositions such as increased customer trust, loyalty, and brand image.

\section{A. Services Provided}

Virtual travel agencies offer almost all the services delivered by conventional travel agencies, from providing general information to reserving and purchasing tickets, accommodations, and entertainment. In addition, they often provide services that most conventional travel agencies do not offer, such as travel tips provided by people who have experienced certain situation (e.g., a visa problem), electronic travel magazines, fare comparisons, currency conversion calculators, fare tracking, (free e-mail alerts on low fares to and from a city and favorite destination), worldwide business and place locators, an outlet for travel accessories and books, experts' opinions, major international and travel news, detailed driving maps and directions within the United States and several other countries (see biztravel.com), chat rooms and bulletin boards, and frequent-flier deals. In addition, some offer several other innovative services, such as online travel auctions.

\section{B. Special Services}

Many online travel services offer travel bargains. Consumers can go to special sites, such as those offering stand by tickets, to find bargain fares. Lastminute.com offers very low airfares and discounted accommodations prices to fill otherwise-empty seats and hotel rooms. Last minute trips can also be booked on americanexpress.com, sometimes at a steep discount. Special vacation destinations can be found at priceline.com, tictaravel.com, stayfinder.com, and greatmentals.com. Flights.com offers cheap tickets and also Eurail passes. If a person needs to access the Internet while they are travelling, they can access cyberaptive.com for a list of about 5,000 Internet cafes around the world. Similar information is available via many portals such as Yahoo, MSN, or Skype.

Also of interest are sites that offer medical advice and services for travelers. This type of information is available from the World Health Organization (who.int), governments (e.g., cdc.gov/travel), and 
private organizations (e.g., tripprep.com, medicalert.com, webmd.com).

\section{Wireless Services}

Several airlines (e.g., Cathay Pacific, Delta, Qantas) allow customers with WAP (Wireless Application Protocol) cell phones (cell phone with Internet access) to check their flight status, update frequent flyer miles, and book flights. In the summer of 2001, Singapore Airlines became the first airline to offer customers global flight alerts via short message service (SMS). Users register the flight for which they want to receive an alert at singaporeair.com and specify when they wish to receive the alert and provide their phone number. British Air offers a broadband Internet connection for passengers on board (initially for first and business class). As of 2003, Lufthansa offers Wi-Fi Internet connections for laptop (for a fee).

\section{Direct Marketing}

Airlines sell electronic tickets over the Internet. When a person purchases an electronic ticket online by (or by phone), all they have to do when they arrive at the airport is enter their credit card at an electronic kiosk and they will get their boarding pass. Alternatively, the traveler can get the boarding pass at the ticket counter.

Using direct marketing techniques, airlines are able to build customer profiles and target specific customers with tailored offers. Many airlines offer "special" or "cyber offers" on their Web sites (e.g., cathaypacific.com). Recently, almost all airlines offer booking, seat selection, Web check-in, automated flight status service visa SMSs; frequent-flyer point claiming, personalized services, and more.

\section{Alliances and Consortia}

Airlines and other travel companies are creating alliances to increase sales or reduce purchasing cost. For example, some consortia aggregate participants' Internetonly fares. Several alliances exist in Europe, the United States, and Asia. For example, zuji.com is a travel portal dedicated to AsiaPacific Travelers. It specializes in tour packages in the region. The company also has a booking engine for travel agents who keep their customers.

\section{Benefits and Limitations of Online Travel Services}

The benefits of online travel services to travelers are enormous. The amount of free information is tremendous, and it is accessible at any time from any place. Substantial discounts can be found, especially for those who have time and patience to search for them. Providers of travel services also benefit: Airlines, hotels, and cruise lines are selling otherwise-empty spaces. Also, direct selling saves the provider's commission and its processing.

Online travel services do have some limitations. First, many people do not use 
the Internet. Second, the amount of time and the difficulty of using virtual travel agencies may be significant, especially for inexperienced Internet surfers. Finally, complex trips of those that require stopovers may not be available online because they require specialized knowledge and arrangements, which may be better done by a knowledgeable, human travel agent. Therefore, the need for travel agents as intermediaries remains, at least for the immediate future. However, as we will show later, intelligent agents may lessen some of these limitations, further reducing the reliance on travel agents.

\section{Impact Of EC On the Travel Industry}

Bloch and Segev predict that travel agencies as we know them today will disappear. Only the value-added activities of travel agencies will not be automated, and these activities will be performed by travel organizations that will serve certain targeted markets and customers[9]. Travel superstores, which will provide many products, services, and entertainment, may enter the industry, as will innovative individuals operating as travel agents from their homes. A more recent analysis on the impact of online travel services on the travel industry is provided by Standing and Vasudavan[10].

With the increased popularity of online reservations, several service providers, such as the large hotel chains, have found that an additional intermediary has appeared between them and the customers: Consumers who used to order accommodations directly from a hotel are now using the Internet to compare prices and frequently are buying from intermediary (such as Hotwire.com) that provides them with the lowest price. The large hotel chains now offer similar services (e.g., see Hilton.com).

\section{E. Corporate Travel}

The corporate travel market is huge and has been growing rapidly in recent years. Corporations can use all of the travel services mentioned earlier. However, many large corporations receive additional services from large travel agencies. To reduce corporate travel costs, companies can make arrangements that enable employees to plan and book their own trips. Using online optimization tools provided by travel companies (such as those offered at rosenbluth.com, companies can try to reduce travel costs even further. Travel authorization software that checks availability funds and compliance with corporate guidelines is usually provided by travel companies such as Rosenbluth international. Another vendor in the corporate travel market is Amadeus Global Travel Distribution (Amadeus.com), via eTravel.com, which provides marketing, distribution, and IT services to automate and manage online booking. 


\section{F. Intelligent Agents in Travel Services}

There is no doubt that EC will play an even greater role in the travel industry in the future. One area that is very promising is the use of software (intelligent) agents. The agents emulate the work and behavior of human agents in executing organizational processes, such as travel authorization[11] or planning[12]. Each agent is capable of acting autonomously, cooperatively, and collectively to achieve the stated goal. The system increases organizational productivity by carrying out several tedious watchdog activities, thereby freeing humans to work on more challenging and creative tasks.

Intelligent agents could be involved in buyer-seller negotiations, as shown in the following scenario: You want to take a vacation in Hawaii. First you called a regular travel agent who gave you the impression he was too busy to help you. Finally, though, he gave you a plan and a price that you do not like. A friend suggested that you use a software agent instead. Here is how the process works: First you enter your desired travel destination, dates, available budget, special requirements, and desired entertainment to your online agent residing on your computer. The software agent then "shops around," entering the Internet and communicating electronically with the database of airlines, hotels, and other vendors. The agent attempts to match your requirements against what is available, negotiating with the vendors' agents. These agents may activate other agents to make special arrangements, cooperate with each other, activate multimedia presentations, or make special inquiries. Within minutes the software agent returns to you with suitable alternatives. You have a few questions and want modifications. No problems. Within a few minutes, the agent will provide replies. Then, it is a done deal. No waiting for busy telephone operators and no human errors. Once you approve the deal, the intelligent agent will make the reservations, arrange for payments, and even report to you about any unforeseen delays in your departure.

\section{CONCLUSION}

There is no one commonly agreed definition of e-commerce or e-business. Thus, there is a need to clarify terms being used and explain the context in which they are being applied. E-commerce has an impact on three major stakeholders, namely society, organizations and customers (or consumers). There are a number of advantages, which include cost savings, increased efficiency, customization and global marketplaces. There are also limitations arising from e-commerce which apply to each of the stakeholders. These include information overload, reliability and security issues, and cost of access, social divisions and difficulties in policing the Internet. Successful e-commerce involves understanding the limitations and minimizing the negative impact while at the same time maximizing the benefits. 
Related to Travel and Tourism Services Online, even though they have enormous benefit effects but also they have limitations. The amount of free information is tremendous, and it is accessible at any time from any place. Substantial discounts can be found, especially for those who have time and patience to search for them. Providers of travel services also benefit: Airlines, hotels, and cruise lines are selling otherwise-empty spaces. Also, direct selling saves the provider's commission and its processing. However online travel services do have some limitations. First, many people do nose the Internet. Second, the amount of time and the difficulty of using virtual travel agencies may be significant, especially for inexperienced Internet surfers. Finally, complex trips of those that require stopovers may not be available online because they require specialized knowledge and arrangements, which may be better done by a knowledgeable, human travel agent. Therefore, the need for travel agents as intermediaries remains, at least for the immediate future.

\section{REFERENCESS}

[1] Turban, Efraim. Electronic Commerce, A Managerial Perspective, Pearson Prentice Hall, 2004.

[2] http://www.investopedia.com/terms/e/e lectronic-retailing-e-

tailing.asp\#axzz2AymWkQJ1 (accessed October 2012).

[3] V. Zwass, 'Structure and macro-level impacts of electronic commerce: from technological infrastructure to electronic marketplaces', http://www.mhhe. com/business/mis/zwass/ecpaper.ht $\mathrm{ml}$ (accessed October 2012).

[4] T. Seideman, 'What Sam Walton learned from the Berlin airlift', Audacity: The Magazine of Business Experience, Spring 1996, pp. 52-61.

[5] Bloch, M., and A. Segev. "The Impact of Electronic Commerce on the Travel Industry." Proceeding 30 ${ }^{\text {th }}$ Annual HICSS, Maui, HI, January 1997.

[6] Standing, C., and T. Vasudavan. "The Impact of Electronic Commerce on the Travel Agency Sector. "Journal of Information Technology Cases and Applications 3, no. 1 (2001).

[7] E. Turban, J. Lee, D. King and H.M. Chung, Electronic Commerce: A Managerial Perspective. Prentice Hall, 1999.

[8] www.whatis.com/ecommerce (accessed October 2012).

[9] P. Timmers, Electronic Commerce Strategies and Models for Business-toBusiness Trading. John Wiley \& Sons, 2000.

[10] http://www.straighton.com/ecommerce_definition.htm (accessed October 2012).

[11] Bose, K. "Intelligent Agents Framework for Developing Knowledge-Based DSS for Collaborative Organizational Processes." Expert System with Application 11, p. 3 (1996).

[12] Camacho, D., et al. Intelligent Travel Multi-Agent System no. 4 (2001). 